\title{
Retroviral Infection Is Limited by Brownian Motion
}

\author{
A.S. CHUCK,,$^{1,3}$ M.F. CLARKE, ${ }^{2}$ and B.O. PALSSON ${ }^{1,4}$
}

\begin{abstract}
Replication-defective retroviruses are frequently used as gene carriers for gene transfer into target cells. Here we show that the short half-lives of retroviruses limit the distance that they can effectively travel in solution by Brownian motion, and thus the possibility of successful gene transfer. This physicochemical limitation can be overcome, and effective contact between the retroviral gene carrier and the target cell can be obtained, by using net convective flow of retrovirus-containing medium through a layer of target cells. Using model cell lines (NIH-3T3 and CV-1), it was shown that gene transfer rates can be increased by more than an order of magnitude using the same concentration infection medium. High transduction rates could be obtained even in the absence of polycations, such as Polybrene, which heretofore have been required to achieve reasonable transduction rates. This development may play an important role in realizing human gene therapy.
\end{abstract}

\section{OVERVIEW SUMMARY}

Retroviruses have short half-lives and therefore can only travel a limited distance by random Brownian motion in infection medium before deactivating. This distance is only a few hundred microns, and this constraint is shown to limit gene transfer rates. This limitation can be overcome by slow flow of the infection medium vertically through the target cell bed and gene transfer rates can be substantially increased.

\section{INTRODUCTION}

$\mathbf{T}$ The ability to introduce DNA into human cells is the basis for the burgeoning field of gene therapy (for reviews, see Anderson, 1984; Miller, 1990, 1992a; Brenner, 1993; Mulligan, 1993). Replication-defective retroviruses have received much attention as vehicles to carry the foreign DNA into many human cell types (Cepko et al., 1984; Miller and Buttimore, 1986; Markowitz et al., 1988; Larrick and Burck, 1991). The process of retroviral infection involves many steps (Dubois-Dalcq et al., 1984): the initial step is that virus must make contact with the cell; this is followed by specific binding of virus onto a cellsurface protein; the virus is then internalized; the viral RNA is reverse-transcribed into DNA; the double-stranded DNA enters the nucleus; and finally the retrovirus derived DNA is integrated into the target cell's genome. The last step of DNA integration is believed to require cell division (Springett et al., 1989; Miller et al., 1990; Roe et al., 1993). The overall success of the infection, as determined by expression of the delivered gene, thus depends on the probability of success of each step of the series.

In this communication, we analyze the first step of this series of events and focus on the factors that determine the frequency of contact between the virus and the target cell. The initial encounter of the virus with the target cell is governed by a predictable physicochemical process-random Brownian motion.

\section{ANALYSIS OF THE KINETICS OF VIRUS-CELL ENCOUNTER}

Typically, infection is carried out in a system where a liquid layer containing the retrovirus is placed on top of a bed of target cells. The physics of this infection system may be described by three processes occurring simultaneously (Fig. 1): (i) Brownian motion of the retrovirus, (ii) decay of the retrovirus, and (iii) adsorption, or capture, of the retrovirus by the target cell. A retrovirus is a colloidal particle with a density similar to that of tissue culture medium, $1.16-1.18 \mathrm{~g} / \mathrm{ml}$ (Lowy, 1985). Its root mean square displacement $(l)$ by Brownian motion over time $(t)$ can be described by (Einstein, 1905):

\footnotetext{
${ }^{1}$ Department of Chemical Engineering and ${ }^{2}$ Department of Internal Medicine, University of Michigan, Ann Arbor, MI 48109.

${ }^{3}$ Amgen, Inc., Thousand Oaks, CA 91320.

${ }^{4}$ Department of Bioengineering, University of California at San Diego, La Jolla, CA 92093-0412.
} 


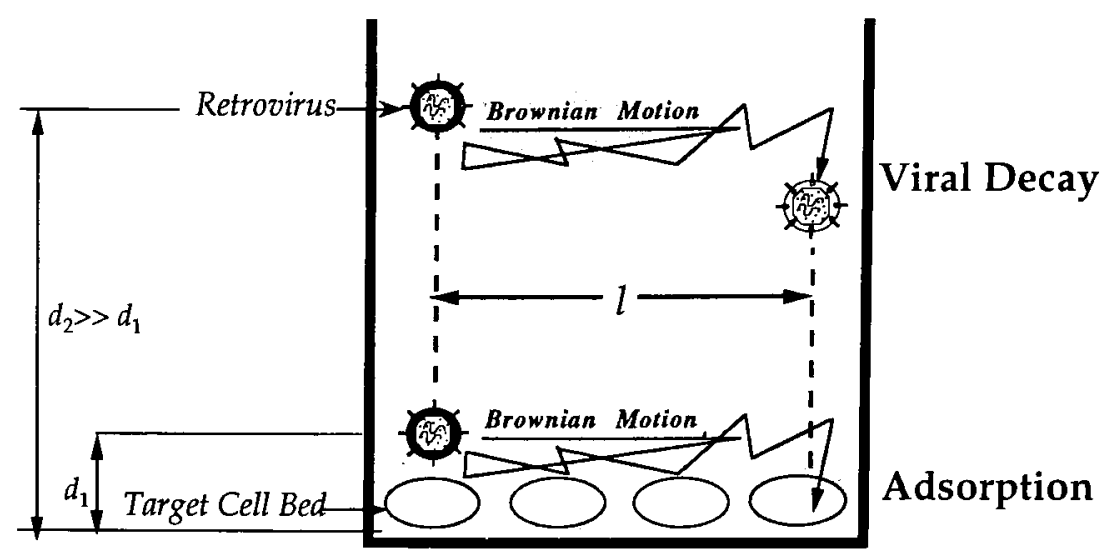

FIG. 1. Static transduction. The schematic shows how a retrovirus' distance from the target cell bed affects the probability of it being adsorbed. The virus close to the bed, at $d_{1}$, has a high probability of being adsorbed, whereas the virus further away, at $d_{2}$, decays over the same time period and cannot reach the target cell. Each retrovirus travels an average distance $l$ by Brownian motion over the time period of interest.

$$
l=\sqrt{2 D t}
$$

where $D$ is the diffusion coefficient. The numerical value of the diffusion constant for a retrovirus can be estimated from the Stokes-Einstein equation (e.g., see Cussler, 1984) to be approximately $6.5 \times 10^{-8} \mathrm{~cm}^{2} / \mathrm{sec}$ using a viral diameter of $100 \mathrm{~nm}$ (Dubois-Dalcq et al., 1984), a temperature of $37^{\circ} \mathrm{C}$, and a medium viscosity of $0.007 \mathrm{~g} / \mathrm{cm}-\mathrm{sec}$.

Retroviral half-lives $\left(t_{0.5}\right)$ are generally short (Levin and Rosenak, 1976; Sanes et al., 1986; Layne et al., 1989; Paul et al., 1993; Kotani et al., 1994). We have measured the half-life for a murine amphotropic retrovirus produced by the $\psi$ CRIP packaging cell line (Danos and Mulligan, 1988) to be about 5-8 hr at $37^{\circ} \mathrm{C}$ (Chuck, 1995). Using the appropriate numerical values for the diffusion coefficient and half-life in Equation (1), we estimate the distance that an average retroviral particle can travel within one half-life $\left(l_{0.5}\right)$ to be $480-610 \mu \mathrm{m}$. Since tissue culture procedures typically use liquid depths of $2-5 \mathrm{~mm}$, the majority of retroviruses in the infection medium, i.e., those above a level of $480-610 \mu \mathrm{m}$, will not be able to reach the cell bed within one half-life.

Based on the physics of the viral capture process, the probability of capture is expected to be inversely proportional to the particle's distance from the surface (of capture) (Berg, 1983)the target cell bed-and the time of capture proportional to the square of this distance (Equation 1). Thus, only those particles closest to the target cells will be captured efficiently and within the time span of the retroviral half-life. Were it not for the short half-life, all the retrovirus particles would reach the target cell surface given an infinite period of time.

The importance of distance between the virus particle and target is depicted in Fig. 1, which shows schematically the retrovirus particle's Brownian motion close to the target cell (at distance $d_{1}$ ) and far from the target (at distance $d_{2}$ ). The retrovinus close to the target bed is able to strike it many times, greatly increasing the chance of adsorbing to the target cell and binding to a target cell receptor. The retrovirus initially far away from the target may travel the same mean distance $(l)$, but decays before being adsorbed onto the target cells.
The probability of a retrovirus particle adsorbing to a target cell will to a first approximation follow mass action kinetics, where the rate of capture is proportional to the densities of the colliding entities:

$$
\text { rate of adsorption }=k C_{V} \mathbf{C}_{\mathbf{T}}
$$

where $C_{V}$ is the virus density (number of viruses/volume) close to the target cells, $C_{T}$ is the target bed cell density (number of cells/area), and $k$ is a second-order rate constant characterizing the adsorption event. Thus, the number of cells transduced is expected to be proportional to both the initial target cell density $\left(C_{T 0}\right)$ and initial retroviral concentration $\left(C_{V O}\right)$ for fixed transduction times. This prediction is experimentally verified below.

The importance of high target cell density and retroviral concentration for obtaining greater numbers of transduced cells has been emphasized in the literature (Belmont et al., 1988; Bodine et al., 1990; Lynch and Miller, 1991; Hughes et al., 1992; Buchschacher, 1993; Cassel et al., 1993; Rettinger et al., 1993; Kotani et al., 1994). However, it remains that individual retroviruses located at increasing distances from the target cell bed have decreasing probability of ever reaching the target cells, if their movement is due only to Brownian motion. Thus, the number of cells transduced is not expected to increase with additional numbers of viruses located at increasing distances. Again, this prediction is experimentally verified below, where increasing distances are achieved by increasing volumes of virus solution overlaying a target cell bed.

How can the limitations of time and distance for capture imposed by random Brownian motion be overcome? If the motion of the retrovirus is directed toward the target cells, the frequency of virus-cell encounters would increase. The virus can be directed, or carried in this way, by fluid flow. Fluid flow is usually implemented by agitation, or mixing of the target cell culture. However, microhydrodynamics are such that laminar hydrodynamic boundary layers form close to solid surfaces-such as cell growth surfaces in standard cell culture plasticware-even in well-mixed flows. These boundary 
layers have flows that are parallel to the solid surface, and their thickness (Schlichting, 1955; Levich, 1962) will be on the order of the penetration distance of the virus, as defined above $\left(l_{0.5}\right)$. Thus, even with bulk fluid agitation, the final encounter of the virus and the target cell is governed by Brownian motion.

This hydrodynamic limitation can be overcome by first seeding the target cells onto a porous surface and then flowing a virus solution directly through the target cell bed. In this way, net fluid flow can be induced over distances shorter than those defined by the viral penetration distance and retroviruses located initially far away from the target cell bed are brought close to the target cells within a controllable length of time. By using a convective fluid flow distributed down to cellular dimensions to drive the virus toward the target cells, we do not rely on Brownian motion to deliver the virus to the target cells, but the fluid motion itself. In the experiments presented below, two model cell lines are used, CV-1 and NIH-3T3, to show increases in transduction efficiencies with this "flow-through" gene transfer technique. Its performance is compared with the traditional method in which there is no net fluid movement, what is termed here as "static transduction."

\section{MATERIALS AND METHODS}

\section{Cell culture}

Target cell lines, CV-1 and NIH-3T3, were seeded at 3,000 cells $/ \mathrm{cm}^{2}$ (unless otherwise stated) in either six-well plates or on collagen membranes 1 day prior to infection. The collagen membranes (Transwell-COL cell culture inserts from Costar, Cambridge, MA) were of $0.4 \mu \mathrm{m}$ pore size and $24.5 \mathrm{~mm}$ diameter. The retrovirus packaging cell line (produced by transfecting a pMFG vector containing a lacZ gene into $\psi \mathrm{CRIP}$ ) was kindly provided by Dr. James Wilson (construction of a similar vector is described in Wilson et al., 1988). Producer cells were thawed every 6 weeks and grown in 10-ml tissue culture dishes (Falcon, Becton Dickinson, Franklin Lakes, NJ). Both the target and producer cell lines were grown with $10 \%$ calf serum supplement (GIBCO, Grand Island, NY) in DMEM and were cultured at $37^{\circ} \mathrm{C}$ and $5 \% \mathrm{CO}_{2}$.

\section{Retrovirus supernatant}

Medium that was conditioned for $24 \mathrm{hr}$ by a confluent monolayer of producer cells was filtered through $0.4-\mu \mathrm{m}$ poresized filters (low protein binding Sterile Acrodisc, Gelman, Ann Arbor, MI). Virus medium harvested from producer cell cultures was assigned a relative retroviral concentration value of 1.0. This rather arbitrary assignment was necessary due to the batch-to-batch variation of retroviral titer that occurs with producer cell lines (Miller, 1992b; Paul et al., 1993), where the viral productivity of a producer cell declines with each succeeding passage. Variable retroviral concentrations were made by diluting the virus supernatant with growth medium. A relative retroviral concentration of 0.1 was used for infecting cultures that would later be assayed (for lac $Z$ expression) by 5 -bromo-4-chloro-3-indolyl- $\beta$-D-galactoside (X-Gal) staining. Similarly, viral concentrations of 0.5 were used for infecting cultures that would be assayed by flow cytometry. Polybrene (Aldrich, Milwaukee, WI) was added to $4 \mu \mathrm{g} / \mathrm{ml}$ (unless otherwise stated). Negative controls (mock infections) were prepared by adding Polybrene (at the same levels as in the retrovirus supernatant) to growth medium. These controls were carried out using both the static and flow-through transduction procedures.

\section{Static transductions}

Static transductions were carried out on cell culture inserts in parallel with flowthrough transductions, unless stated otherwise. The substrates used in this work (i.e., tissue culture plastic or Transwell-COL) did not affect either cell growth or transduction efficiency (Chuck, 1995). Static transductions were carried out as follows: medium was removed from target cell cultures and replaced by $2 \mathrm{ml}$ of virus solution. The cultures were then incubated for the determined transduction time, after which the retrovirus solution was removed and fresh growth medium was added. Cultures were assayed for lac $Z$ expression gene 3-4 days later.

\section{Flow-through transductions}

Virus medium was gravity flowed through the seeded collagen membranes at an average flowrate of $\sim 1 \mathrm{ml} / \mathrm{hr}$ for the transduction period (up to $10 \mathrm{hr}$ ) at $37^{\circ} \mathrm{C}$. A schematic of this setup is depicted in Fig. 3A. Flow-through transductions were always conducted in parallel with static transductions, using the same preparation of virus solution and target cell seedings. After the transduction period, the virus medium was removed from the reservoir above the target cell bed and fresh growth medium was added. Cultures were left to incubate (without media flow) for 3-4 days until the time of assay.

\section{$X$-Gal staining procedure}

Each cell culture well or insert was washed twice with $2 \mathrm{ml}$ of Hank's buffered saline solution (HBSS, GIBCO) and fixed with $1.5 \mathrm{ml}$ of $2 \%$ (vol/vol) formaldehyde (Sigma) and $0.2 \%$ (vol/vol) of glutaraldehyde (Sigma) for $5 \mathrm{~min}$. Following fixation, the cells were washed once more in HBSS before adding $1.5 \mathrm{ml}$ of staining solution. The staining solution consisted of $50 \mu \mathrm{l}$ of $[20 \mathrm{mg} / \mathrm{ml} \mathrm{X-Gal} \mathrm{powder} \mathrm{dissolved} \mathrm{in} N, N$-dimethylformamide (DMF, Sigma)] per milliliter of $5 \mathrm{mM} \mathrm{K} \mathrm{K}_{3} \mathrm{Fe}(\mathrm{CN})_{6}$ (Sigma), $5 \mathrm{mM} \mathrm{K} \mathrm{K}_{4} \mathrm{Fe}(\mathrm{CN})_{6} \cdot 3 \mathrm{H}_{2} \mathrm{O}$ (Sigma), and $2 \mathrm{~m} M \mathrm{MgCl} 2$ (Sigma) in phosphate-buffered saline (PBS). The samples were incubated for $1-4$ days at $37^{\circ} \mathrm{C}$ to allow any blue cell color to develop, and numbers of colony-forming units (CFU, at 2-8 cells/colony) in each well were counted.

\section{Flow cytometry}

Each Transwell-COL was washed three times with $2 \mathrm{ml}$ of HBSS and the cells removed by $1 \mathrm{ml}$ of trypsin (GIBCO) exposure. Fresh growth medium was then added to resuspend and wash the cells. Reagents from the FluoReporter $\operatorname{lac} Z$ gene detection kit (Molecular Probes, Eugene, OR) were used to prepare and stain the cells. The cells were incubated in a $37^{\circ} \mathrm{C}$ water bath for $5 \mathrm{~min}$ and then loaded with substrate by hypotonic shock as follows: $50 \mu \mathrm{l}$ of $2 \mathrm{~m} M$ fluorescein di- $\beta$-D-galactopyranoside (FDG) was added to each tube at $37^{\circ} \mathrm{C}$ and left to 
incubate for $90 \mathrm{sec}$. The tubes were then immersed in ice, and $450 \mu \mathrm{l}$ of ice-cold PBS with human IgG (Sigma) and $1 \mathrm{mg} / \mathrm{ml}$ propidium iodide (PI) was added. A Coulter EPICS flow cytometer was used to determine percentage of cells transduced, as indicated by positive green fluorescence (Chuck and Palsson, 1991).

\section{RESULTS}

The bilinear dependence of number of transduced cells on both target cell and retrovirus densities was shown experimentally. Either the initial virus density $\left(C_{V O}\right)$ or target cell density $\left(C_{T O}\right)$ was kept constant while varying the other (Fig. 2). Experimentally, these relationships were found to be linear, as shown in Fig. 2, A and B, thus confirming the expectation that infectivity is proportional to the likelihood of a collision between the retrovirus and the target cell, as described by Equation 2.

The number of transduced cells did not depend on the total number of viruses present. Experiments were performed where the number of transduced cells was measured over time for different amounts of virus supematant overlaying the target cell bed. Different numbers of virus were obtained by varying the depths of retrovirus solution in seeded tissue culture wells. Retroviral concentrations, $\mathrm{CV}-1$ target cell densities, and transduction time were held constant. Figure $2 \mathrm{C}$ shows that no significant difference in the number of cells transduced was observed as the depth of the solution layer exceeded the mean displacement distance $l_{0.5}$ for all time points. Even though there was a higher number of retroviruses in the infection medium, they did not lead to an increase in the number of cells transduced, confirming the diffusion limitation predicted by the analysis presented above.

Vertical flow-through could substantially increase the number of cells transduced (Fig. 3). Two target cell lines, NIH-3T3 and $\mathrm{CV}-1$, were used to examine the flow-through method of retrovirus delivery. Static transductions (no fluid flow) were carried out on collagen membranes with infection fluid overlaying the target culture. For static transductions, the target cells were exposed to $2 \mathrm{ml}$ of virus medium for the entire 10 -hr period, which should yield a maximal number of transduced cells (Fig. 2C plateau). Using flow-through, the degree of transduction increased linearly with the volume of retrovirus solution flowed. The number of flow-transduced cells far exceeded the number of static-transduced cells (Fig. 3B,C). Thus, the number of transduced cells was proportional to the number of retroviruses contacting the target cell bed. Visually, the increase in the number of transduced target cells was quite dramatic, as shown in Fig. 4. This experimental result is again consistent with the theoretical predictions made above.

Polybrene, a polycation, has been essential to obtaining high transduction efficiencies in RNA virus (static) infection systems (Manning et al., 1971; Cometta and Anderson, 1989). Polybrene is believed to increase contact between the virus and target cell by overcoming (repulsive) electrostatic forces between the like-charged virus and cell (Coelen et al., 1983). On the basis of the analysis presented above, one would expect that the convective force applied in the flow-through procedure will alleviate the need for Polybrene. The data in Fig. $3 \mathrm{C}$ confirm
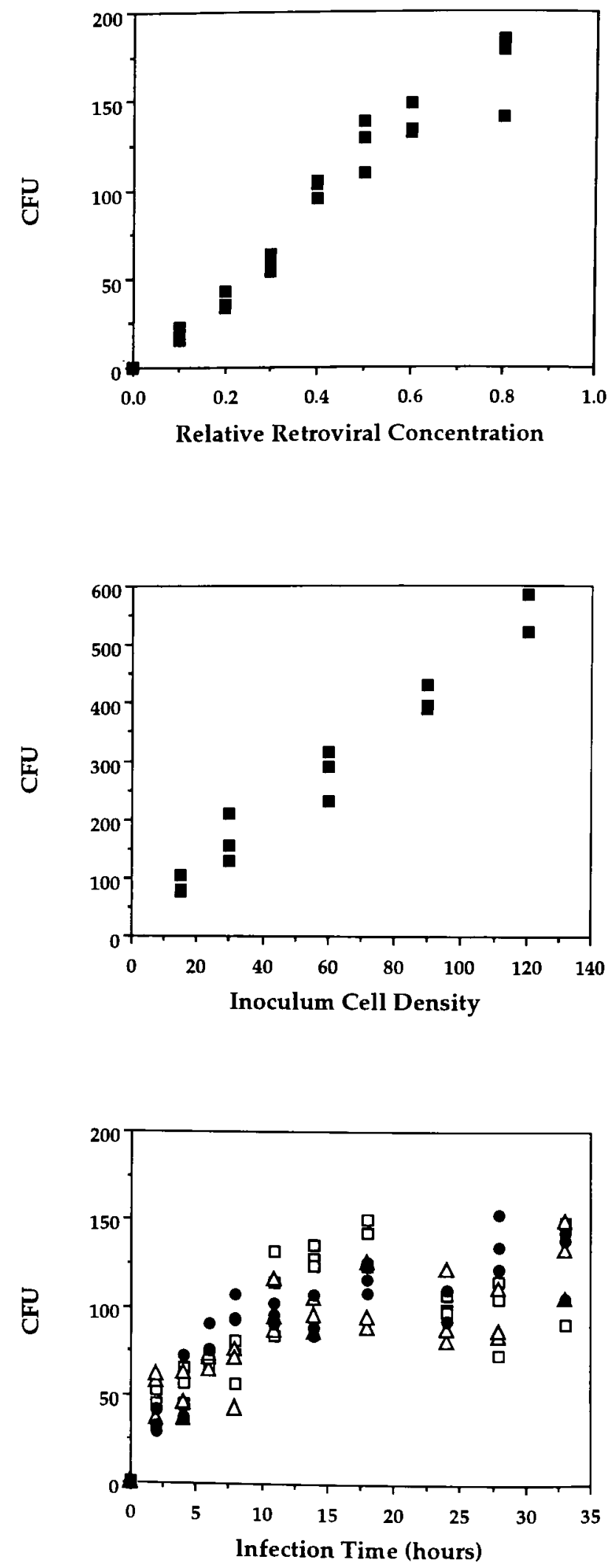

FIG. 2. Gene transfer (as enumerated by CFU) after static transduction is shown as a function of initial retroviral concentration (relative units) with an 8-hr transduction time (A), (B) target cell density (units in thousands of CV-1 cells $\mathrm{per} /$ well) with an 8-hr transduction time, and time, with increasing depths of infection solution (C): $520 \mu \mathrm{m}(500 \mu \mathrm{l}=$ $\square), 832 \mu \mathrm{m}(800 \mu \mathrm{l}=\Delta)$, and 1,559 $\mu \mathrm{m}(1500 \mu \mathrm{l}=0)$. All measurements were performed in triblicate. Individual data points are shown. 

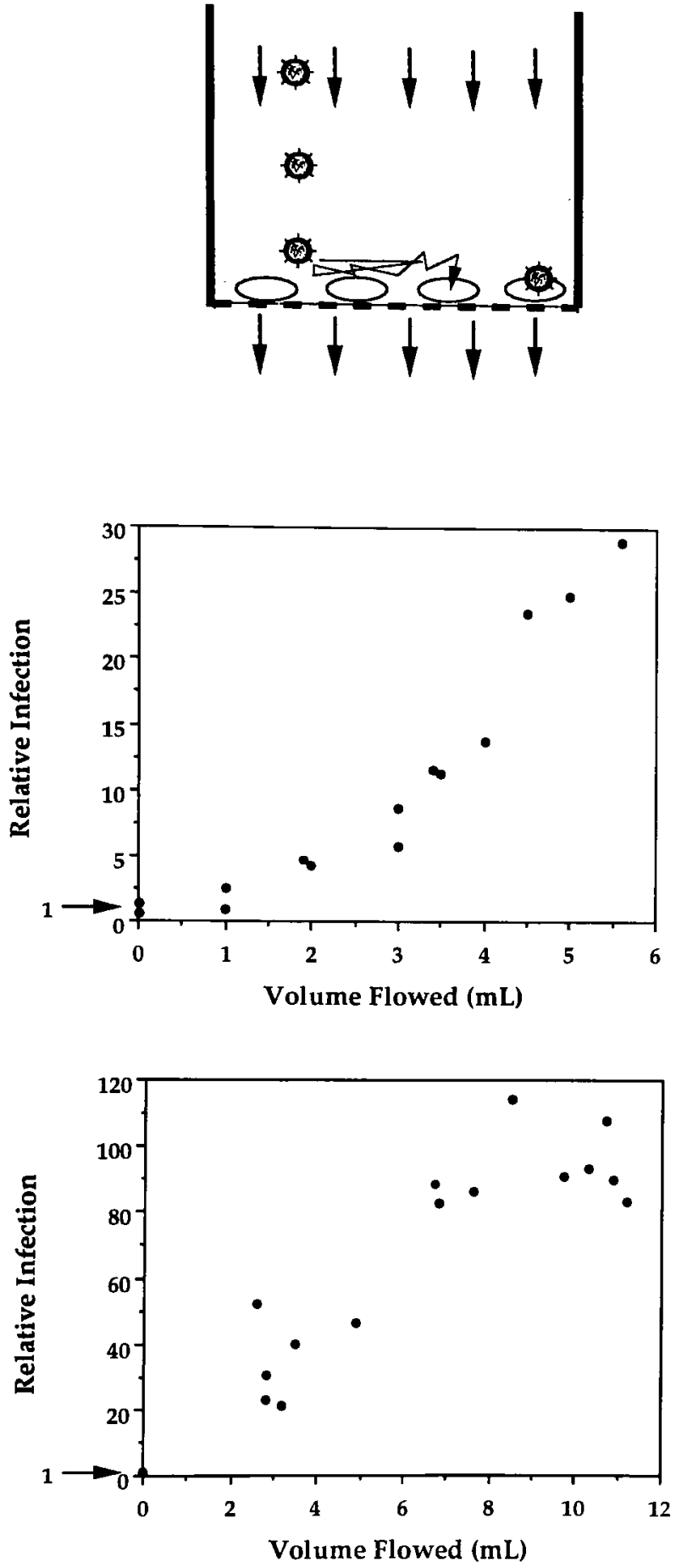

FIG. 3. Transduction in flowing medium. A schematic of the retrovirus solution flowing through the target cell bed is shown in A. Transduction enhancements using virus solution flow (relative to a no-flow, or static transduction) are shown for CV-1 cells in B and NIH-3T3 cells in C. No Polybrene was used in infecting the NIH-3T3 cells.

this expectation: More than 35\% of 3T3 target cells were transfected without the use of Polybrene. Using the static method, less than $1 \%$ of the cells could be transduced.

Several control experiments were performed to verify the above results. Mock infections using both the static and flowthrough methods of exposure resulted in no cells being transduced, as determined by both X-gal and flow cytometry. Thus, the flow-through procedure did not result in a greater background of (false) gene expression. Also, various methods of mixing the infection cultures (continuous shaking and periodic tilting) did not result in any additional cells being transduced (Chuck, 1995) over those obtained by static virus exposures. The enhancements from flow-through were not due to the collagen substrate; similar enhancements as reported above were observed with polyester membranes with Polybrene present (Chuck, 1995). In addition, the numbers of cells recovered $(\sim 3$ days post infection, at the time of analysis) and the percentages of cells transduced were the same for static transductions whether the target cells grew on membrane substrate or tissue culture plastic. Finally, no difference in the number of cells recovered was observed for flowthrough versus static transductions, or for the concentration of retrovirus used in either of these transduction methods (Chuck, 1995).

\section{DISCUSSION}

In widely used methods of static transductions using conditioned medium from packaging cell lines, the transport of retrovirions to target cells is, in all probability, limited by the slow delivery by Brownian motion relative to the half-life of the retrovirus. Thus, the virus adsorption rate is dictated by the virus mass transfer rate to the target cell bed. It has been demonstrated here that most of the volume of virus solution overlaying a target cell bed does not contribute toward increasing the transduction rate. Under these diffusion limitations, the number of virions reaching the cell bed can be increased by increasing the number of retroviruses per unit volume in the infection medium, but high retroviral titers have proven difficult to obtain (Belmont et al., 1988; Bodine et al., 1990; Lynch and Miller, 1991). Retrovirus-mediated gene transfer has been shown to be enhanced through co-culture of the target cells on the virus-producing cell line (Hock and Miller, 1986; Bodine et al., 1991). The reasons for this enhancement can be explained by the current results: The higher rates are due to the proximity of target cells to viral source.

The limitations imposed by Brownian motion can be managed using directed convective flow. By inducing liquid (and thus retroviral) motion in the desired direction only, we do not rely on Brownian motion to deliver the virus to the target cells. Fluid flow through a porous cell growth surface allows for very effective contact between the gene carrier and the target cell. The net rate of transport of retrovirus to the target cell bed, and thus the net rate of adsorption, can be significantly increased. Flow-through should be an attractive method of delivery of other gene transfer vehicles (e.g., adenoviruses, adeno-associated viruses, and liposomes), which also have very low diffusivities.

Selective motion of viruses can be obtained by means other than fluid flow. Elevated gravity will increase the settling rate of the virus. Indeed, it has been shown that centrifugation does enhance retrovirus-mediated gene transfer into peripheral blood lymphocytes from humans and nonhuman primates (Bunnel $e t$ 

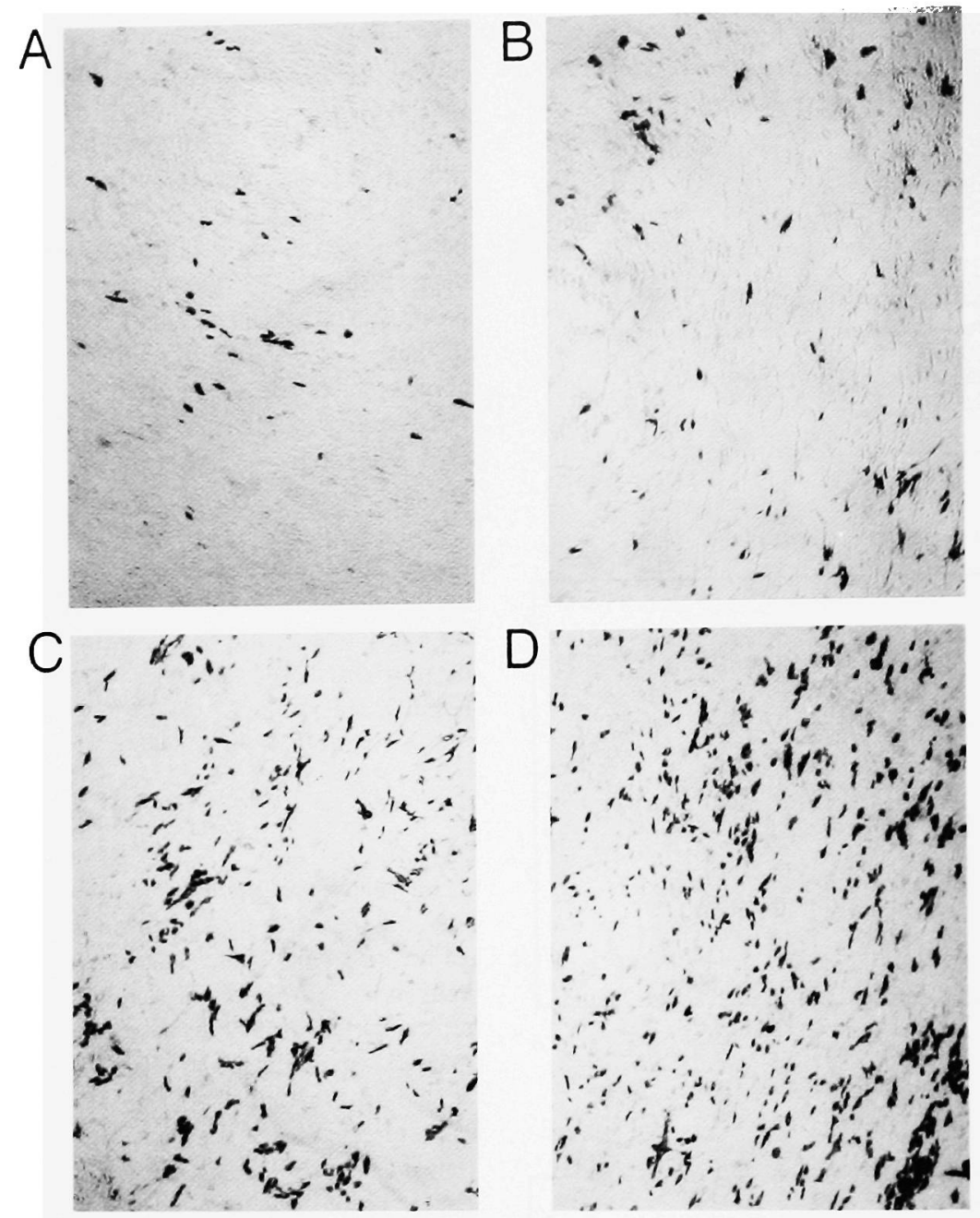

FIG. 4. Photographs of transduced CV-1 target cells. Two milliliters of virus medium in static transduction (A) is compared to increasing volumes in flow-through transduction: $1 \mathrm{ml}(\mathrm{B}), 3.5 \mathrm{ml}(\mathrm{C})$, and $5 \mathrm{ml}(\mathrm{D})$.

al., 1995). The mechanism leading to this increase in gene transfer rate obtained by centrifugation is outlined in this manuscript. This study thus shows that eliminating the limitation of Brownian motion will also lead to increased gene transfer into primary human cells.

The virus can be adhered to the membrane without having the target cells present at the time of fluid flow. The target cells can be introduced subsequently and allowed to grow on a viruscontaining surface (Chuck and Palsson, 1996b). This approach allows for the separation of the process of localization of the virus and the exposure to the target cell. This separation offers a number of advantages for gene therapy because the medium containing the gene carrier and the cell culture medium can be separated. Retroviral supernatants are known to contain products that alter the growth of the target cells (Xu et al., 1994). Using the flow-through approach, one can "load" the gene carriers onto the growth surface and then remove the infection medium prior to introducing the target cells in their own growth medium. The same procedure can be used for a gene carrier that needs to be present in serum-free medium, as is the case with liposomes, and target cells that have to be in serum-containing medium. Other advantages of the flow-through approach for gene therapy include insensitivity to titer (Chuck and Palsson, 1996a) and shortened virus exposure times (Chuck and Palsson, 1996b).

In summary, we have shown that retrovirus-mediated gene transfer is limited by random Brownian motion. This limitation can be overcome by directing the motion of the retrovirus toward the target cells. The flow-through approach may significantly help the development of gene therapy (Chuck and Palsson, 1996a), which is currently hampered by low gene transfer rates (Buchshacher, 1993; Cassel et al., 1993).

\section{ACKNOWLEDGMENTS}

We thank James Wilson for kindly providing the retroviral packaging cell line used in this work and Abraham Lenhoff for valuable discussions. This work was supported by Aastrom Biosciences Inc. 


\section{REFERENCES}

ANDERSON, W.F. (1984). Prospects for human gene therapy. Science 226, 401-409.

BELMONT, J.W., MACGREGOR, G.R., WAGER-SMITH, K., FLETCHER, F.A., MOORE, K.A., HAWKINS, D., VILLALON, D., CHANG, S.M.-W., and CASKEY, C.T. (1988). Expression of human adenosine deaminase in murine hematopoietic cells. Mol. Cell. Biol. 8, 5116-5125.

BERG, H.C. (1983). Random Walks in Biology (Princeton University Press, New Jersey) pp. 37-47.

BODINE, D.M., MCDONAGH, K.T., BRANDT, S.J., NEY, P.A., AGRICOLA, B., BYRNE, E., and NIENHUIS, A.W. (1990). Development of a high-titer retrovirus producer cell line capable of gene transfer into rhesus monkey hematopoietic sten cells. Proc. Natl. Acad. Sci. USA 87, 3738-3742.

BODINE, D.M., MCDONAGH, K.T., SEIDEL, N.E., and NIENHUIS, A.W. (1991). Survival and retrovirus infection of murine hematopoietic stein cells in vitro: Effects of 5-FU and method of infection. Exp. Hematol. 19, 206-212.

BRENNER, M.K. (1993). Gene transfer into human hematopoietic progenitor cells: A review of current clinical protocols. J. Hematother. 2, 7-17:

BUCHSCHACHER, G.L., JR. (1993). Molecular targets of gene transfer therapy for HIV infection. J. Am. Med. Assn. 269, 2880-2886.

BUNNEL, B.A., MUUL, L.M., DONAHUE, R.E., BLAESE, R.M., and MORGAN, R.A. (1995). High-efficiency retroviral mediated gene transfer into human and non-human primate peripheral blood lymphocytes. Proc. Natl. Acad. Sci. USA 92, 7739-7743.

CASSEL, A., COTTLER-FOX, M., DOREN, S., and DUNBAR, C.E. (1993). Retroviral-mediated gene transfer into CD34-enriched human peripheral blood stem cells. Exp. Heinatol. 21, 585-591.

CEPKO, C.L., ROBERTS, B.E., and MULLIGAN, R.C. (1984). Construction and applications of a highly transmissable retrovirus shuttle vector. Cell 37, 1053-1062.

CHUCK, A.S. (1995). "Directed Retroviral Motion as a Means of Enhancing Gene Transfer for Gene Therapy." Ph.D. Thesis, The University of Michigan, Ann Arbor, MI.

CHUCK, A.S., and PALSSON, B.O. (1991). Population balance between producing and nonproducing hybridoina clones is very sensitive to serum level, state of inoculum, and medium coinposition. Biotech. Bioeng. 39, 354-360.

CHUCK, A.S., and PALSSON, B.O. (1996a). Consistent and high rates of gene transfer can be obtained using flow-through transduction over a wide range of retroviral titers. Hum. Gene Ther. 7, 743-750.

CHUCK, A.S., and PALSSON, B.O. (1996b). Membrane adsorption characteristics determine the kinetics of flow-through transductions. Biotech. Bioeng. 51, 260-270.

COELEN, R.J., JOSE, D.G., and MAY, J.T. (1983). The effect of hexadimethrine bromide (polybrene) on the infection of the primate retroviruses SSVI/SSAV1 and BaEV. Arch. Virol. 75, 307-311.

CORNETTA, K., and ANDERSON, W.F. (1989). Protamine sulfate as an effective altemative to polybrene in retroviral-mediated gene transfer: implications for human gene therapy. J. Virol. Methods 23, 1187-1194.

CUSSLER, E.L. (1984). Diffusion: Mass Transfer in Fluid Systems. (Cambridge University Press, New York) p. 118.

DANOS, O., and MULLIGAN, R.C. (1988). Safe and efficient generation of recombinant retroviruses with amphotropic and ecotropic host ranges. Proc. Natl. Acad. Sci. USA 85, 6460-6464.

DUBOIS-DALCQ, M., HOLMES, K.V., and RENTIER, B. (1984). Assembly of Enveloped RNA Viruses. (Springer-Verlag, New York) pp. 149-170.

EINSTEIN, A. (1905). Über die von der molekularkinefischen Theorie der Wärme geforderte Bewegung von in ruhenden Flüssigkeiten suspendierten Teilchen. Annalen der Physik. 17, 549-560.
HOCK, R.A., and MILLER, A.D. (1986). Retrovirus-mediated transfer and expression of drug resistance in human haematopoietic progenitor cells. Nature 320, 275-277.

HUGHES, P.F.D., THACKER, J.D., HOGGE, D., SUTHERLAND, H.J., THOMAS, T.E., LANDSORP, P.M., EVANS, C.J., and HUMPHRIES, R.K. (1992). Retroviral gene transfer to primitive normal and leukemic hematopoietic cells using clinically applicable procedures. J. Clin. Invest. 89, 1817-1824.

KOTANI, H., NEWTON, P.B. II, ZHANG, S., CHIANG, Y.L., OTTO, E., WEAVER, L., BLAESE, R.M., ANDERSON, W.F., and MCGARRITY, G.J. (1994). Improved methods of retroviral vector transduction and production for gene therapy. Hum. Gene Ther. 5, 19-28.

LARRICK, J.W., and BURCK, K.L. (1991). Gene Therapy: Application of Molecular Biology (Elsevier Science Publishing Co., New York) pp. 77-93.

LAYNE, S.P., SPOUGE, J.L., and DEMBO, M. (1989). Quantifying the infectivity of human immunodeficiency virus. Proc. Natl. Acad. Sci. USA 86, 4644-4648.

LEVICH, V.G. (1962). Physicochemical Hydrodynamics. (PrenticeHall, Inc., NJ).

LEVIN, J.G., and ROSENAK, M.J. (1976). Synthesis of murine leukemia virus proteins associated with virions assembled in actinomycin D-treated celis: Evidence for persistence of viral messenger RNA. Proc. Natl. Acad. Sci. USA 73, 1154-1158.

LOWY, D.R. (1985). Transformation and oncogenesis: Retrovinuses. In Virology. B.N. Fields, D.M. Knipe, J.L. Melnick, R.M. Chanock, and B. Roizman, eds. (Raven Press, New York) pp. 237.

LYNCH, C.M., and MILLER, A.D. (1991). Production of high-titer helper virus-free retroviral vectors by cocultivation of packaging cells with different host ranges. J. Virol. 65, 3887-3890.

MANNING, J.S., HACKETT, A.J., and DARBY, N.B., JR. (1971). Effect of polycations on sensitivity of BALB/3T3 cells to murine leukemia and sarcoma virus infectivity. Appl. Microbiol. 22, 1162-1163.

MARKOWITZ, D., GOFF, S., and BANK, A. (1988). A safe packaging cell line for gene transfer: Separating viral genes on two different plasmids. J. Virol. 62, 1120-1124.

MILLER, A.D. (1990). Retrovirus packaging cells. Hum. Gene Ther. 1, 5-14.

MILLER, A.D. (1992a). Human gene therapy comes of age. Nature 357, 455-460.

MILLER, A.D. (1992b). Retroviral vectors. Curr. Topics Microbiol. Immunol. 158, 1-24.

MILLER, A.D., and BUTTIMORE, C. (1986). Redesign of retrovirus packaging cell lines to avoid recounbination leading to helper virus production. Mol. Cell. Biol. 6, 2895-2902.

MILLER, D.G., ADAM, M.A., and MILLER, A.D. (1990). Gene transfer by retrovirus vectors occurs only in cells that are actively replicating at the time of infection. Mol. Cell. Biol. 10, 4239-4242.

MULLIGAN, R.C. (1993). The basic science of gene therapy. Science 260, 926-932.

PAUL, R.W., MORRIS, D., HESS, B.W., DUNN, J., and OVERELL, R.W. (1993). Increased viral titer through concentration of viral harvests from retroviral packaging cell lines. Hum. Gene Ther. 4, 609-615.

RETTINGER, S.D., KENNEDY, S.C., WU, X., SAYLORS, R.L., HAFENRICHTER, D.G., FLYE, M.W., and PONDER, K.P. (1993). Liver-directed gene therapy: Quantitative evaluation of promoter elements by using im vivo retroviral transduction. Proc. Natl. Acad. Sci. USA 91, 1460-1464.

ROE, T., REYNOLDS, T., YU, G., and BROWN, P. (1993). Integration of nurine leukemia virus DNA depends on mitosis. EMBO J. 12, 2099-2108.

SANES, J.R., RUBENSTEIN, J.L.R., and NICOLAS, J-F. (1986). Use of a recombinant retrovirus to study post-implantation cell lineage in mouse embryos. EMBO J. 5, 3133-3142. 
SCHLICHTING, H. (1955). Boundary-Layer Theory. (McGraw-Hill, Inc., New York).

SPRINGETT, G.M., MOEN, R.C., ANDERSON, S., BLAESE, R.M., and ANDERSON, W.F. (1989). Infection efficiency in T lymphocytes with amphotropic retroviral vectors is cell cycle dependent. J. Virol. 63, 3865-3869.

WILSON, J.M., JEFFERSON, D.M., CHOWDHURY, J.R., NOVIKOFF, P.M., JOHNSTON, D.E., and MULLIGAN, R.C. (1988). Retrovirus-mediated transduction of adult hepatocytes. Proc. Natl. Acad. Sci. USA 85, 3014-3018.

XU, L.C., YOUNG, H.A., BLANCO, M., KESSLER, S., ROBERTS, A.B., and KARLSSON, S. (1994). Poor transduction efficiency of human hematopoietic progenitor cells by a high-titer amphotrophic retrovirus producer cell clone. J. Virol. 68, 7634-7636.

Address reprint requests to: Dr. Bernhard O. Palsson Department of Bioengineering University of California, San Diego 9500 Gilman Drive La Jolla, CA 92093-0412

Received for publication January 4, 1996; accepted after revision May 13, 1996. 
This article has been cited by:

1. Ching-An Peng. 2009. Analysis of Gene Transfer Rate with Immobilized Retroviral Vectors. Annals of the New York Academy of Sciences 1161:1, 26-33. [CrossRef]

2. Sarah L. Taylor, Ahad A. Rahim, Nigel L. Bush, Jeffrey C. Bamber, Colin D. Porter. 2007. Targeted retroviral gene delivery using ultrasound. The Journal of Gene Medicine 9:2, 77-87. [CrossRef]

3. Pedro Lei, Stelios T. Andreadis. 2005. Stoichiometric limitations in assembly of active recombinant retrovirus. Biotechnology and Bioengineering 90:7, 781-792. [CrossRef]

4. Young Jik Kwon, Ching-An Peng. 2005. High-yield retroviral production using a temperature-modulated two-stage operation. Biotechnology and Bioengineering 90:3, 365-372. [CrossRef]

5. Akira Tempaku. 2005. Random Brownian Motion Regulates the Quantity of Human Immunodeficiency Virus Type-1 (HIV-1) Attachment and Infection to Target Cell. JOURNAL OF HEALTH SCIENCE 51:2, 237-241. [CrossRef]

6. Natalia LandDzuri, Joseph M. Le Doux. 2005. Complexation of retroviruses with charged polymers enhances gene transfer by increasing the rate that viruses are delivered to cells. The Journal of Gene Medicine 6:12, 1304-1319. [CrossRef]

7. Christian Plank, Martina Anton, Carsten Rudolph, Joseph Rosenecker, Florian Krötz. 2003. Enhancing and targeting nucleic acid delivery by magnetic force. Expert Opinion on Biological Therapy 3:5, 745-758. [CrossRef]

8. C. Plank, U. Schillinger, F. Scherer, C. Bergemann, J.-S. Rémy, F. Krötz, M. Anton, J. Lausier, J. Rosenecker. 2003. The Magnetofection Method: Using Magnetic Force to Enhance Gene Delivery. Biological Chemistry 384:5, 737-747. [CrossRef]

9. Tong Zhang, Tom C. Tsang, David T. Harris . 2003. Efficient Transduction of Murine Primary T Cells Requires a Combination of High Viral Titer, Preferred Tropism, and Proper Timing of TransductionEfficient Transduction of Murine Primary T Cells Requires a Combination of High Viral Titer, Preferred Tropism, and Proper Timing of Transduction. Journal of Hematotherapy Stem Cell Research 12:1, 123-130. [Abstract] [PDF] [PDF Plus]

10. Bharat Bajaj, Shahram Behshad, Stelios T. Andreadis . 2002. Retroviral Gene Transfer to Human Epidermal Keratinocytes Correlates with Integrin Expression and Is Significantly Enhanced on FibronectinRetroviral Gene Transfer to Human Epidermal Keratinocytes Correlates with Integrin Expression and Is Significantly Enhanced on Fibronectin. Human Gene Therapy 13:15, 1821-1831. [Abstract] [PDF] [PDF Plus]

11. Gene G. Olinger, Mohammed Saifuddin, Melanie L. Hart, Gregory T. Spear . 2002. Cellular Factors Influence the Binding of HIV Type 1 to CellsCellular Factors Influence the Binding of HIV Type 1 to Cells. AIDS Research and Human Retroviruses 18:4, 259-267. [Abstract] [PDF] [PDF Plus]

12. Nils Loewen, Michael P. Fautsch, Mary Peretz, Cindy K. Bahler, J. Douglas Cameron, Douglas H. Johnson, Eric M. Poeschla . 2001. Genetic Modification of Human Trabecular Meshwork with Lentiviral VectorsGenetic Modification of Human Trabecular Meshwork with Lentiviral Vectors. Human Gene Therapy 12:17, 2109-2119. [Abstract] [PDF] [PDF Plus]

13. Christopher R. Logg, Chien-Kuo Tai, Aki Logg, W. French Anderson, Noriyuki Kasahara . 2001. A Uniquely Stable Replication-Competent Retrovirus Vector Achieves Efficient Gene Delivery in Vitro and in Solid TumorsA Uniquely Stable Replication-Competent Retrovirus Vector Achieves Efficient Gene Delivery in Vitro and in Solid Tumors. Human Gene Therapy 12:8, 921-932. [Abstract] [PDF] [PDF Plus]

14. Young Jik Kwon, Hong Yu, Ching-An Peng. 2001. Enhanced retroviral transduction of 293 cells cultured on liquid-liquid interfaces. Biotechnology and Bioengineering 72:3, 331-338. [CrossRef]

15. Mauro Di Ianni, Sabrina Di Florio, Gigliola Venditti , Franca Falzetti , P. Mannoni , Massimo F. Martelli , Antonio Tabilio . 1999. T Lymphocyte Transduction with Herpes Simplex VirusThymidine Kinase (HSV-tk) Gene: Comparison of Four Different Infection ProtocolsT Lymphocyte Transduction with Herpes Simplex VirusThymidine Kinase (HSV-tk) Gene: Comparison of Four Different Infection Protocols. Journal of Hematotherapy Stem Cell Research 8:6, 645-652. [Abstract] [PDF] [PDF Plus]

16. Charles M. Roth, Martin L. Yarmush. 1999. Nucleic Acid Biotechnology. Annual Review of Biomedical Engineering 1:1, 265-297. [CrossRef]

17. Tuan Huy Nguyen, Jean-Christophe Pages, Denis Farge, Pascale Briand, Anne Weber . 1998. Amphotropic Retroviral Vectors Displaying Hepatocyte Growth Factor-Envelope Fusion Proteins Improve Transduction Efficiency of Primary 
HepatocytesAmphotropic Retroviral Vectors Displaying Hepatocyte Growth Factor-Envelope Fusion Proteins Improve Transduction Efficiency of Primary Hepatocytes. Human Gene Therapy 9:17, 2469-2479. [Abstract] [PDF] [PDF Plus]

18. Tuan Huy Nguyen, Jean-Christophe Pagès, Denis Farge, Pascale Briand, Anne Weber. 1998. Amphotropic Retroviral Vectors Displaying Hepatocyte Growth Factor-Envelope Fusion Proteins Improve Transduction Efficiency of Primary HepatocytesAmphotropic Retroviral Vectors Displaying Hepatocyte Growth Factor-Envelope Fusion Proteins Improve Transduction Efficiency of Primary Hepatocytes. Human Gene Therapy 9:17, 2469-2479. [Abstract] [PDF] [PDF Plus]

19. MARIANNE HUTCHINGS, KOICHI MORIWAKI, DAGMAR DILLOO, THOMAS HOFFMANN, SARAH KIMBROUGH, HANS E. JOHNSEN, MALCOLM K. BRENNER, HELEN E. HESLOP. 1998. Increased Transduction Efficiency of Primary Hematopoietic Cells by Physical Colocalization of Retrovirus and Target CellsIncreased Transduction Efficiency of Primary Hematopoietic Cells by Physical Colocalization of Retrovirus and Target Cells. Journal of Hematotherapy 7:3, 217-224. [Abstract] [PDF] [PDF Plus]

20. Steve J. White, Sean M. Page, Paris Margaritis, George G. Brownlee. 1998. Long-Term Expression of Human Clotting Factor IX from Retrovirally Transduced Primary Human Keratinocytes In VivoLong-Term Expression of Human Clotting Factor IX from Retrovirally Transduced Primary Human Keratinocytes In Vivo. Human Gene Therapy 9:8, 1187-1195. [Abstract] [PDF] [PDF Plus]

21. Stylianos Andreadis, Almyra O. Fuller, Bernhard O. Palsson. 1998. Cell cycle dependence of retroviral transduction: An issue of overlapping time scales. Biotechnology and Bioengineering 58:2-3, 272-281. [CrossRef]

22. CAROLINE G.L. LEE, KUAN-TEH JEANG, MALCOLM A. MARTIN, IRA PASTAN, MiCHAEL M. GOTTESMAN. 1997. Efficient Long-Term Coexpression of a Hammerhead Ribozyme Targeted to the U5 Region of HIV-1 LTR by Linkage to the Multidrug-Resistance GeneEfficient Long-Term Coexpression of a Hammerhead Ribozyme Targeted to the U5 Region of HIV-1 LTR by Linkage to the Multidrug-Resistance Gene. Antisense and Nucleic Acid Drug Development 7:5, 511-522. [Abstract] [PDF] [PDF Plus]

23. Cassandra Nyberg-Hoffman, Paul Shabram, Wei Li, Daniel Giroux, Estuardo Aguilar-Cordova. 1997. Sensitivity and reproducibility in adenoviral infectious titer determination. Nature Medicine 3:7, 808-811. [CrossRef] 